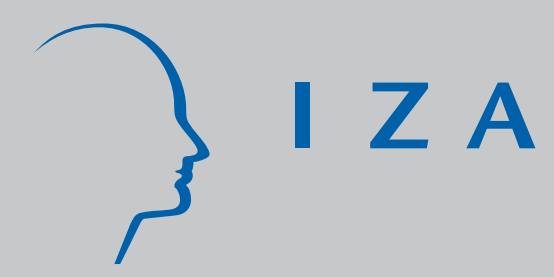

IZA DP No. 3644

Businesswomen in Germany and Their Performance by Ethnicity: It Pays to Be Self-Employed

Amelie F. Constant

August 2008

Forschungsinstitut

zur Zukunft der Arbeit

Institute for the Study

of Labor 


\title{
Businesswomen in Germany and Their Performance by Ethnicity: It Pays to Be Self-Employed
}

\author{
Amelie F. Constant \\ DIW DC, Georgetown University and IZA
}

Discussion Paper No. 3644

August 2008

IZA

P.O. Box 7240

53072 Bonn

Germany

Phone: +49-228-3894-0

Fax: +49-228-3894-180

E-mail: iza@iza.org

\begin{abstract}
Any opinions expressed here are those of the author(s) and not those of IZA. Research published in this series may include views on policy, but the institute itself takes no institutional policy positions.

The Institute for the Study of Labor (IZA) in Bonn is a local and virtual international research center and a place of communication between science, politics and business. IZA is an independent nonprofit organization supported by Deutsche Post World Net. The center is associated with the University of Bonn and offers a stimulating research environment through its international network, workshops and conferences, data service, project support, research visits and doctoral program. IZA engages in (i) original and internationally competitive research in all fields of labor economics, (ii) development of policy concepts, and (iii) dissemination of research results and concepts to the interested public.
\end{abstract}

IZA Discussion Papers often represent preliminary work and are circulated to encourage discussion. Citation of such a paper should account for its provisional character. A revised version may be available directly from the author. 
IZA Discussion Paper No. 3644

August 2008

\section{ABSTRACT}

\section{Businesswomen in Germany and Their Performance by Ethnicity: It Pays to Be Self-Employed}

In this paper I assert that the entrepreneurial spirit can also exist in salaried jobs. I study the determinants of wages and the labor market success of two kinds of entrepreneurial women in Germany - self-employed and salaried businesswomen - and investigate whether ethnicity is important in these challenging jobs. Employing data from the German Socioeconomic Panel I estimate selection adjusted wage regressions for both types of businesswomen by country of origin. I find that self-employment offers businesswomen a lucrative avenue with higher monetary rewards, albeit for a shorter spell. If salaried businesswomen went into selfemployment, they would receive considerably higher wages and for at least 30 years. However, if self-employed businesswomen went into salaried jobs, their wages would decline, suggesting that it is the self-employment sector that offers better opportunities and monetary success. Self-employed women in Germany fare well and most importantly, success does not depend on their ethnicity.

JEL Classification: M13, J23, J15, J61, J31

Keywords: businesswomen, entrepreneurship, self-employment, economics of minorities, immigrants wage differentials

Corresponding author:

Amelie F. Constant

DIW DC

$1800 \mathrm{~K}$ Street, NW

Office Suite 716

Washington, DC 20006

USA

E-mail: constant@diwdc.org

\footnotetext{
* I thank Klaus F. Zimmermann for stimulating discussions and suggestions on this paper. I also thank two anonymous referees for helpful comments. Financial support for this research from Volkswagen Foundation for the IZA project on "The Economics and Persistence of Migrant Ethnicity" is gratefully acknowledged.
} 


\section{Introduction}

Entrepreneurs are individuals who create or seize market opportunities, pursing their goals while facing uncertainty and bearing personal and professional risks. While big companies create jobs and stimulate innovation, self-employment also contributes to job creation and economic growth, alleviating the welfare burden and leading many to economic and social advancement. Businesswomen, in particular, create a "gender edge" that can generate additional business, increase sales and investor appeal. Female-owned enterprises in the U.S. are considered the "new face of the economy" and women are becoming a substantial client-base for financial institutions.

A country's social norms and perceptions can encourage or stifle the entrepreneurial spirit. In the U.S., "being one's own boss" is not only socially acceptable and encouraged, but also intertwined with prestige, money, and power. Business-owners are critical components of the American economy and highly regarded. While there are still more male entrepreneurs, 6.5 million American businesses are owned by women and yield almost $\$ 951$ billion in receipts annually (U.S. Bureau Economic Censuses). Although less than 5\% of America's Top 500 executives are women (Forbes.com), businesswomen in management, administration, and executive positions make inroads and now comprise $46 \%$ of all managers and administrators.

In Germany, entrepreneurial activity is comparatively moderate, although this is rapidly changing. While the majority of decision-makers in German businesses and authorities are still male, $30 \%$ of all executives are women. In keeping with the spirit of the Lisbon Agenda to promote a "more entrepreneurial culture and a supportive environment for small and medium size enterprises,” self-employment in Germany is on the rise. In 1998, recognizing that women are broadly underrepresented in small and medium businesses, and lack of start-up capital is a major obstacle, the government enacted a funding scheme for start-ups of women-owned businesses (OECD, 2000). Immigrants are particularly entrepreneurial; over the last decade, more foreigners entered self-employment than native Germans. In April 2001, 257,000 of the 3.1 million foreigners in the German workforce were self-employed.

Businesswomen are engaging in profit-oriented enterprises and act as sole proprietors or business executives. In the salaried sector, they have made inroads in executive, administrative, and managerial occupations, applying their talents and offering their services to someone else's company. They devise plans and strategies, make risky decisions, identify economic opportunities, and assume responsibilities, enjoying a high degree of autonomy and relative job security.

Self-employment is another outlet for entrepreneurial talents, offering independence, higher self- 
worth and job satisfaction, albeit with higher risk. These attributes can prompt entrepreneurs to choose self-employment, even at lower wages than in the salaried sector. For women especially, self-employment offers flexibility to combine a career with family and domestic responsibilities, and valuable convenience to work from home or close to home. For many women, self-employment is also an attractive solution for escaping “glass ceiling” obstacles and unwelcoming corporate culture. However, self-employment comes with long hours of work.

For immigrants, self-employment is a way of climbing the socio-economic ladder, a way out of unemployment and a road to earnings assimilation; a sign that they are "making it" and putting down roots. Research on male native-immigrant employment shows that not only do self-employed immigrants have higher annual incomes than salaried workers, they also have higher incomes than comparable selfemployed natives (Borjas, 1986; Lofstrom, 2002; Constant and Shachmurove, 2006; Taylor, 2001; Blanchflower et al., 2001; Audretsch et al., 2002; and Constant and Zimmermann, 2004, 2006). While some argue that individuals are pulled rather than pushed into self-employment (Fairlie and Meyer, 1996), others support both factors, and show that ethnic minorities are no more entrepreneurial than others and do not earn more than comparable whites (Clark and Drinkwater, 1998).

While a few studies concentrate on gender differences in self-employment (Lohmann, 2001; McManus, 2001; Georgellis and Wall, 2000; Constant and Schultz-Nielsen, 2004; and Wagner, 2004), the entrepreneurial activities of women, especially salaried businesswomen, is an under-researched area in the economic literature. This paper attempts to close this gap using German data.

A data inspection confirms some ethnic diversity and provides evidence that the self-employed businesswomen earn less than their salaried counterparts. However, these findings disappear with proper controls of individual and market characteristics and even reverse. The paper continues with Section 2 presenting the empirical design, variables and hypotheses. Section 3 describes the dataset and sample populations, and Section 4 presents the results and discusses counterfactuals. The last section summarizes and concludes.

\section{Framework, variables, and hypotheses}

\subsection{Design of the estimation of wages}

Because women workers may not be a random sample of the female population, their wages need to be appropriately adjusted for selection. For the occupational selection I employ a multinomial logit (MNL), where rational women are sorted into four different alternative distinct occupations: (i) self-employment, 
(ii) salaried businesswoman, (iii) other types of jobs in the salaried sector, and (iv) not employed.

Freelance professionals, independent academics, and other businesses comprise the self-employed group. This group is quite diverse, including pediatricians, hairdressers, translators, restaurant owners, etc. The cohesiveness of this group comes from their desire to be independent, autonomous, risk-taking, and flexible. They may not always have the high qualifications required in a corporate position but have the ability to start-up a company and be on their own. The second occupation consists of employees with highly qualified and extensive managerial duties at the executive level (head of departments, managing directors, head of large firms, etc.). The main characteristic of this group is that while these highly educated women can be industrious, venturesome, and entrepreneurial, they exercise these talents within the more "secure" environment of the salaried sector. Security includes health insurance, sick leave, paid vacation, etc. Being constrained to find start-up fund is another commonality. The other wage work category comprises other women workers in blue- or white-collar jobs, and the last occupation - the reference group in the multinomial logit - pertains to housewives. While I also estimate selection into “other jobs,” I concentrate on the entrepreneurial businesswomen’s selection and wages. The latter are unique because they are in positions that require them to identify and seize opportunities and to make risky decisions that could jeopardize their business or their job, to show courage and make profits.

In MNL I include all employed and not employed and the characteristics that can best determine the labor supply and entrepreneurial sorting: human capital, intergenerational links, variables that bear witness to socio-political attachments to Germany and general economic well-being, other attitudinal variables, proxies for risk attitudes, macroeconomic conditions, ethnicity, and controls picking up family responsibilities and labor market availability. ${ }^{1}$

The results of MNL are fed into the estimation of selection adjusted wages with Lee’s (1983) twostage method. Accordingly, from each of the three employment probabilities, I estimate a selection term $\lambda$ that I insert as an additional regressor in each of the three wage regressions: self-employed businesswomen are adjusted for selection into self-employment, salaried businesswomen are adjusted for selection in this occupation, and so are employees in other non-entrepreneurial jobs. Lastly, I adjust for heteroscedasticity.

The dependent variable in all three estimations is the natural logarithm of the hourly wage, created from self-reported monthly earnings and weekly work hours. The term wages refers to pay per hour for one's labor, while earnings refer to wages multiplied by the number of hours one works. In the semilogarithmic specification the estimated coefficient denotes the percentage change of the dependent variable due to a unit change in the independent variable. In this estimation, the explanatory variables are 
sufficiently different to ensure identification of the two-stage estimation.

\subsection{Independent variables, hypotheses and predictions}

Following the human capital theory, more education increases productivity; it is in the interest of employers to reward these workers with higher wages. I include the following determinants in the wage regression: (i) pre- and post-migration years of schooling, (ii) vocational training, (iii) health, and (iv) years-since-migration, as well as (v) age, and (iv) familial status. For immigrants, I include ethnicity and citizenship status. I augment the model with labor market wage determinants including: (i) working in a small or average size company, (ii) length of having the business or time in the company, (iii) industry dummies, (iv) Treiman occupational prestige scores, and (v) unemployment over vacancies ratio. Lastly, I control for selection biases.

While years of schooling is the number one determinant of wages, vocational training is a very important form of education that influences and regulates wages and is included in the schooling variable. For immigrants, it is critical to differentiate between pre- and post-migration schooling. I expect wages to significantly increase with additional years of post-migration schooling; pre-migration schooling may or may not be rewarded in the host country. Likewise, healthier individuals should earn more money. Yearssince-migration is the quintessential determinant of immigrants' wages (Chiswick, 1978), and part of immigrants' post-migration human capital. The idea is that the longer immigrants live in the host country, the longer they are exposed to the new culture, mores and rules of the labor market, the better their information set becomes, the easier they can overcome institutional hurdles, and the higher their performance and their earnings are. The effect is expected to be non-linear, with earnings increasing with additional years in the host country at a decreasing rate. The coefficient of the years-since-migration variable and its square (along with the age coefficients) measures the pure assimilation effect for immigrants. That is, it shows the increase in wages beyond the wage growth due to increased experience and seniority that applies to natives only.

The age of the individual is also a powerful determinant of wages. It is expected that when one is younger, wages increase at an expanding rate, but as one becomes older wages increase at a slower rate; I expect to obtain concave age-earnings profiles. While family status can predict wages, the direction of influence is different for men and women. Married men with children portray the image of stable and productive individuals and are therefore rewarded in the labor market. In antithesis, married women with young children may be penalized. It is often argued that they might not be seriously committed to the labor 
force as they might quit at any time due to household responsibilities. Since women bear the brunt of rearing children they may be more prone to absenteeism and low productivity, caused by “decay” in their skills as they move in and out of the labor force.

Immigrants who ascend to citizenship should have higher earnings. In principle, acquiring the German passport indicates a willingness to be part of the new country and a fully fledged citizen, opening doors to more and better jobs and protecting immigrants from discrimination and abuses. The ethnicity of immigrants could also predict their wages; it can capture observed and unobserved individual differences such as differences in endowments that affect productivity, work ethos, culture, race, religious affiliation, the type of selection that characterizes the migrant flow, etc. I anticipate significant wage differences among the different ethnicities.

I control for firm size, because workers in small or average size firms earn less than workers in large firms. Because some industries pay more than others I include 7 industry dummies: (i) service, restaurants, hotels, transport, and other services, (ii) retail, wholesale, and trade, (iii) government (education, health, defense), (iv) manufacturing, (v) construction, (vi) financial and banking industry, and (vii) all other unidentified jobs. Next, I hypothesize that longevity in the business and tenure or seniority in a company are rewarded in the labor market.

Note that within the self-employed businesswomen group there might be a wide variance of jobs. A self-employed businesswoman could be a medical doctor with her own practice or a hair-dresser with her own salon. Likewise, there is heterogeneity within the wage work category and other categories. To capture these differences, I include the Treiman occupational prestige scale that is based on the international classification of occupations ISCO codes. Ranging from 13-78, these prestige scores portray the relative amount of power each occupation commands, in terms of skills, authority, and economic control. I expect that women with higher occupational prestige scores command higher wages.

The state of business cycle can play an important role in the monetary success of businesses and individuals. I expect an inverse relationship between them: the higher the unemployment over vacancies ratio, the lower the wages. Lastly, I include $\lambda$ from the logit estimation to take care of selectivity. A significant $\lambda$ would indicate that the sample of these women workers is not a random sample of the population, and thus, an adjustment is judged necessary. A positive (negative) $\lambda$ would suggest that this non-random sample of workers is drawn from the upper (lower) part of the wage distribution. 


\section{Dataset and characteristics}

\subsection{Dataset}

The empirical analysis is based on the 2002 German Socioeconomic Panel (GSOEP), a nationally representative dataset based on surveys conducted annually since 1984. It includes detailed information on Germans and all legal immigrants, their labor force participation, various aspects of life in Germany, premigration information, and an assortment of attitudinal questions. More importantly, the 2002 data permit a more detailed analysis on the self-employed, as I can differentiate among those in agriculture, free-lance, and other categories including family business.

Excluding those in agriculture, in family business, and enrolled in school, and restricting the analysis to individuals aged 20 to 65 and I end up with 9,444 observations, used in the multinomial logit estimation. Specifically, 428 entrepreneurial women are in self-employment, 775 in paid-employment, 4,722 in other non-entrepreneurial salaried jobs, and 3,615 not working. The five ethnicity groups are: ${ }^{2}$ (i) West Germans, (ii) East Germans, (iii) immigrants from European Union member states, (iv) Eastern European immigrants, mainly from ex-Soviet block countries (Romanians, Yugoslavs, Albanians, Russians, etc.), and (v) “other immigrants” (mostly from developing countries), including Turks (the largest immigrant group in Germany).

For the selection adjusted wage regressions I consider only working women with positive hourly wages. The sample is then further reduced to 5,167 observations, with 320 (6\%) in self-employment, 706 (14\%) in the salaried sector, and 4,141 in other jobs. Because of the smaller size of the immigrant samples I group Eastern Europeans and “other immigrants” together, labeled “non-EU immigrants.” The sample’s ethnicity composition is: 3,715 (73\%) West and 792 (15\%) East Germans, 230 (5\%) EU, and 480 (8\%) non-EU immigrants.

\subsection{Characteristics of the entrepreneurial women}

Table I emphasizes comparisons among the four ethnicity groups across their three employment types, and highlights the respective differences and similarities for women workers with positive valid wages. Overall, Table I illustrates substantial disparities in the labor market among the female workers in the different ethnicity groups. Among the self-employed, European immigrants earn the highest salaries per month, followed by West Germans; East Germans are lagging behind. The lower average wages of East Germans may be in part due to their geographic location, since the new German states have not fully adjusted to the wages of the states in the West even after 12 years of reunification. Non-EU immigrants 
have the lowest earnings. Note that the hourly wages give a slightly different picture because they are adjusted for hours of work. While West Germans work regular full-time hours, East Germans work very long hours, immigrants - especially the non-EU - work less than full-time. All ethnicities in selfemployment earn less than the salaried businesswomen but more than women in other wage work. While for West Germans the wage gap between self-employed and salaried businesswomen is minimal, it is the largest for non-EU immigrants.

\section{$<<$ TABLE I ABOUT HERE $>>$}

Self-employed EU immigrants exhibit the highest longevity in business, having their company on average for 12 years. West Germans rank second in stability with 9 years of business ownership. They, however, have the highest Treiman occupational prestige score followed by immigrants and East Germans. While the prestige difference among the self-employed ethnicities is small, it is noticeable between selfemployed and salaried businesswomen. It is not surprising that the majority of the self-employed businesswomen, especially the East Germans, own small-scale businesses with less than nine employees. Note that self-employment almost always starts as a very small company of one or two people and grows with time if it is successful.

The self-employed are older than salaried businesswomen and those in the other wage group. They are way into their mid-forties, with East Germans being the oldest group of self-employed (47 years old). The vast majority of self-employed is also married. Clearly, the East Germans stand out with the highest levels of education (16 years of schooling); West Germans are also well educated (about 14 years of schooling). Adding up their pre- and post-migration years of education, immigrants are also well educated. This summation might be an overstatement, however, as pre-migration schooling might not be recognized or rewarded in the host country. While European immigrants have six years of schooling and vocational training in Germany and another six from their home countries, non-EU immigrants have eight years of schooling in Germany and eight in their home countries. Interestingly, East Germans and non-EU immigrants, who have the highest levels of schooling, earn less than the others. Self-employed immigrants have been in Germany longer than women in any other occupational type.

The middle tier of Table I shows that salaried businesswomen fare the best monetarily. European immigrants still earn the most Euros, but the gap among nationalities is not as big as among the selfemployed. Consistently, East Germans are lagging behind. While those few East Germans who live in the 
West earn more than those who live in the East, they still earn 10\% less than West Germans. All ethnicities, except the non-EU, work full-time. Both East and West Germans have the longest tenure with the firm (11 years). The Treiman prestige scores for all nationalities in this employment type are high and similar. The majority of these businesswomen works in an average or large size firm, and on average, they are in their early forties. However, there is some variation in their ages, with European immigrants being the youngest. Salaried businesswomen also have the most years of education of women in any employment type, and this educational level is comparable among ethnicities. While the immigrants have some premigration education they have acquired most of their education (about 12 years) in Germany.

For reference, the lower part of Table I presents the characteristics of salaried workers in other nonentrepreneurial jobs. West German women in this category earn the highest wages, but they are closely followed by the other nationalities. All workers in this employment type earn less, have lower Treiman scores, and less education than businesswomen in self- or paid-employment. The majority of these women workers are employed in an average to large size firm, and they are in their late thirties to early forties.

\section{Estimation results on wages}

Table II presents the results on the wage regressions adjusted for selection into self-employment (Column 1), into an entrepreneurial business career (Column 2), and other salaried jobs (Column 3). ${ }^{3}$ Below I concentrate on the statistically significant results. Overall, these results are as expected. Across all types of employment, the wages of working women increase with age at a decreasing rate.

\section{$<<$ TABLE II ABOUT HERE $>>$}

Figure 1 plots the estimated log-wage-age profiles of women in these three types of employment, evaluated at the mean of all other covariates, excluding the selection term $\lambda$. This figure illustrates different paths to success according to employment type. Clearly, entrepreneurial women fare better than other workers. Salaried businesswomen follow a steady up-sloping curve and reach maximum wages at the age of 56. It is interesting that their wages do not decrease as fast after they reach that maximum. Compared to self-employed, they start with higher wages when they first enter the labor market. Their profile cuts through that of self-employed women, showing that they earn less for a good 20 years between the ages of 28 and 49. While they earn more later in their careers until they retire, they never reach the high wages of the self-employed. 


\section{$<<$ FIGURE 1 ABOUT HERE >>}

The log-wage-age profile of the self-employed businesswomen is more concave than the other 2 profiles. It rises high and steep from the beginning, intersects the profile of the salaried businesswomen from below, surpasses it, reaches a maximum at 43 years of age and declines afterwards. That is, after the age of 28 when self- and paid-employed businesswomen reach parity the self-employed enjoy a higher remuneration, all else equal. At younger ages, when self-employed businesswomen first join the labor market, they have lower wages than salaried businesswomen. But their wages increase at a faster rate and reach the top about 13 years earlier than salaried businesswomen. This probably indicates that monetary success through self-employment is short-lived for women in Germany, or that after they establish their business and enjoy success the self-employed move into salaried jobs.

The log-wage-age profile of women in other dependent employment is depicted by the lowest and flattest curve in Figure 1. Their wages increase and decrease slower than the wages of the businesswomen. While they reach a maximum at 60 years of age their wages stay within a very narrow margin, indicating less skilled workers. There are no prospects of parity between these women workers and businesswomen.

Human capital is not a significant determinant of the self-employed businesswomen’s wages. For immigrants, years-since-migration is not significant either. Surprisingly, self-employed businesswomen are penalized when they are married, earning 23\% less than non-married women (Column 1). One of the arguments why women might choose self-employment is that they can easier combine work and family responsibilities. In principle, they do not have to punch a card for a nine-to-five schedule. They can even conduct their business from home while simultaneously satisfying domestic responsibilities. Since they are their own boss, we should not observe any wage disparities for familial reasons. One explanation would be due to the time and energy allocation between the job and the husband. Controlling for children, married women may have to devote more time and energy to the household than when they are not married, especially when they are married to high-profile men. Given the time constraints and limited services, married women in self-employment might not perform 100\%, miss out on opportunities, and their productivity and corresponding wages may be lower. Moreover, being married also means that there is an additional source of income in the household. If the husband provides reliable financial support, then married women might see their business as a supplemental-secondary job or hobby. This leads to a diminished interest to fight for their business and go for profit. Married women may also be less ambitious, deliberately entering into a type of self-employment that is less competitive and "marriage friendly." Of 
course, this spurious correlation cannot be answered from a cross-section.

While the self-employed earn a premium of 3\% when they have a high Treiman prestige score, bad macroeconomic times affect their wages negatively with a $2 \%$ reduction. Controlling for everything else and adjusting for selection into self-employment, the self-employed in manufacturing earn less than in other industries. Among the self-employed, no other ethnicity is significantly different than West Germans. This is interesting in that success in self-employment does not depend on one's country of origin. However, it defies previous findings that self-employed immigrant men earn more than natives. Lastly, while negative, the selection term $\lambda$ is not significantly different than zero, suggesting that the selfemployed businesswomen are randomly drawn from the population.

Column 2 documents some differences and similarities between self-employed and salaried businesswomen. The latter experience a 9\% decrease in their wages for poor health. While there is no significant penalty when they are married, they earn 9\% more when they have young children. An explanation for this could be that the salaried sector offers these women additional compensation for their children or that these women work harder because they have the responsibility of the children. As predicted, businesswomen in this track earn 31\% less when they work in a small firm as opposed to working in a large firm. Note that as Table I shows most businesswomen are in average or large firms. Tenure or seniority with the firm is rewarded although only slightly (1\%). Likewise, having a higher Treiman prestige score also commands $1 \%$ higher wages.

Unfavorable regional macroeconomic conditions are indeed reflected in lower wages. Even these high positioned businesswomen are negatively affected by almost $2 \%$. Wage disparity by industry records that businesswomen in the retail or wholesale industry earn 23\% less than women in other industries. Lastly, I cannot confirm any significant wage differences between West Germans and other ethnicities. This suggests that at this high level of specialization and jobs, where one comes from is irrelevant for one's wages. Similar to the self-employed all ethnicities are equal and do not significantly determine wages. This result is against assimilation literature showing that immigrants earn less than natives in salaried jobs. Years-since-migration is not significant either.

The negative and significant, albeit only at $10 \%$, coefficient of $\lambda$ suggests that salaried businesswomen are not a random sample and rather drawn from the lower end of the distribution, given the characteristics. A possible explanation is that the "better" women, even when they are well educated and entrepreneurial, do not work. This could be consistent with the "male breadwinner" scenario that is still noticeable in Germany. Standard culprits for this are the education and tax system, ${ }^{4}$ coupled with social 
norms that highly encourage and esteem women who stay home when they are married and have children. If one believes in assortative marriage, these women are married well and can afford staying home and enjoy the financial support of their husbands. Single women, on the other hand, may be discouraged to reach the high executive positions or their paths may be blocked.

For comparison, Column 3 reports the wage results for salaried women in other non-entrepreneurial jobs. While they earn more for each additional year of pre- and post-migration education they are penalized for having poor health. Similar to salaried businesswomen, women with young children earn a premium of 3.5\% and are not significantly penalized for being married. Working in small and average size firms comes with a stiff penalty of 35 and 15\% respectively for not working in a large firm. Length of time with the company matters in a positive way, indicating significant, albeit small, seniority effects. A higher Treiman prestige score induces a wage premium and so does working for the government, manufacturing, or financial/banking industries. High regional unemployment to vacancies ratios negatively affect the wages of these workers. This is a $2 \%$ penalty that women in all employment types experience. With regards to ethnicity, I find that - all else equal - East Germans earn 11\% less than West Germans. But there are no significant wage differences between West Germans and other immigrants. The negative and highly significant selection term $\lambda$ indicates that these women - in comparison to those who stay home - are negatively self-selected.

Although self-employed women may opt for monetary rewards and salaried businesswomen may "work for the job," these differences could be related to preferences or personalities. Women often cite family responsibilities and networking as a serious consideration for self-employment. Other reasons might be different forms of discrimination in the salaried sector or lack of proper qualifications. However, there are minimum standards that self-employed must meet to be able to obtain authorization to open a store or a restaurant. Risk-proclivity and risk-aversion are also important personality traits that affect employment sorting. Start-up funding is another serious consideration and often an impediment to self-employment. On the other hand, landing the executive job at a corporation is not easy either. It requires high qualifications and a life in the fast lane.

The mean of the log-hourly-wages shows that salaried businesswomen earn the highest wages; their wages also have the smallest dispersion. While self-employed businesswomen earn less than the former, they have a high standard deviation of wages. This means that some self-employed women are very successful monetarily while others may not be. Naturally all other salaried types of jobs pay less. In sum, regression decomposes what the raw statistics show; the big difference between self- and paid-employed is 
taken by the constant and the rest by the characteristics.

\subsection{Counterfactual analysis}

While self-employed businesswomen fare best monetarily for some years, it is unclear whether this is due to the characteristics of these women or to their type of employment. With a counterfactual analysis, I explore how the self-employed businesswomen would fare if they had the characteristics of the salaried businesswomen. Figure 2 plots these new log-wage-age profiles and juxtaposes them to the original profiles of salaried and self-employed businesswomen.

Clearly, attributing the characteristics and labor market features of the salaried businesswomen to the self-employed raises the latter's profiles. If self-employed businesswomen had the characteristics of their salaried counterparts they would experience a huge and lasting boost in their wages. They manage to minimize the early age disadvantage and crossover at the age of 24 , completely overtaking the wages of the salaried businesswomen until the age of 54. At this time, their wages cross the wages of the salaried businesswomen from above and become lower.

\section{$<<$ FIGURE 2 ABOUT HERE $>>$}

Undoubtedly, this counterfactual shows that self-employed businesswomen would enjoy significantly higher wages had they the characteristics of the salaried businesswomen. Put differently, salaried businesswomen would enjoy a tremendous boost in their wages should they switch to selfemployment. Self-employment is therefore a very lucrative employment strategy for entrepreneurial women in Germany, better than the comparable salaried option. It is interesting that these highly educated businesswomen opt away from the highly rewarding self-employment sector. Possible explanations are that they may be more risk-averse or that they do not have the necessary start-up funds.

If self-employed businesswomen would fare better had they the characteristics of salaried businesswomen, then maybe other women workers could also fare better if they had the characteristics of the salaried businesswomen. However, this is not the case for the other non-entrepreneurial jobs in the salaried sector. If women workers in these jobs were to have the characteristics of the salaried businesswomen, they would experience an improvement in their wages throughout their working lives, but they would never be able to reach the wages of the salaried or the self-employed businesswomen (Figure A1 in the appendix). In this case, even the "exceptional” characteristics of the salaried businesswomen are 
not enough to render their occupations into an equally profitable option. It is, therefore, the selfemployment sector that offers high financial rewards to women entrepreneurs.

If it is the employment sector that makes a difference, then maybe the salaried sector also makes a difference in the businesswomen's performance. The question is then: how would the self-employed women fare if they were to go into the entrepreneurial jobs in the salaried sector? If they are better off, then perhaps the paid-employment sector appreciates their characteristics more and makes them thrive. In Figure 3, I execute this counterfactual by taking the self-employed businesswomen and putting them in the salaried entrepreneurial sector. The new wage-age profile of the self-employed businesswomen who would go to work for a company is juxtaposed to the original wage-age profiles of the self-employed and salaried businesswomen.

\section{$<<$ FIGURE 3 ABOUT HERE $>>$}

The new simulated profile shifts down, demonstrating an overall worsening. This suggests that the salaried sector is not helpful for entrepreneurial women. Specifically, the new profile lies below the selfemployment profile between the ages of 22 and 56. Without a doubt, entrepreneurial women in this age range are better off being self-employed. However, when women are older and looking towards retirement, they are better off going in the salaried sector because they would earn more than if they were selfemployed. In sum, simulations in Figures 2, 3, and A1 reveal that it is the self-employment type that helps entrepreneurial women rich monetary success, especially when they are 25 to 50 years old.

\section{Summary and conclusion}

This paper takes a novel approach at women entrepreneurs by asserting that the entrepreneurial spirit can also exist in salaried jobs; businesswomen can exhibit their entrepreneurship through self-employment or through working for another company in the salaried sector. For reference and contrast, I also study other women workers in non-entrepreneurial jobs. The questions are: How is entrepreneurship rewarded? Does self-employment offer higher payoffs? Are there wage disparities among businesswomen of different ethnicities?

Using the GSOEP I study West Germans, East Germans, EU and non-EU immigrants. Summary statistics reveal that, on average, salaried businesswomen fare better than self-employed businesswomen in terms of monthly earnings. The former have a small standard deviation indicating that they are closer to the mean as a group, while the latter have a high dispersion, suggesting that not all self-employed are very 
successful. The wages of businesswomen in self- or paid-employment vary by ethnicity. Among the selfemployed, EU immigrants earn the highest wages and immigrants from non-EU countries the lowest. Overall, women in self-employment are older, less educated and have lower job prestige scores than salaried businesswomen. With the exception of the EU immigrants, the self-employed also have fewer years in business. Among salaried businesswomen, there are also disparities, albeit not always so dramatic. European immigrants earn the most money, followed by West Germans and non-EU immigrants in a tie and East Germans last.

Selection adjusted results show that the wages of all businesswomen increase with age at a discounting rate. The self-employed reach maximum wages at 43 while salaried businesswomen at 56. Estimated log-wage-age profiles illustrate that self-employed and salaried businesswomen compete for monetary success during their careers. Salaried businesswomen earn more very early in their careers and for a short while. They earn more again later after 50, but they never reach the top high levels of the selfemployed wages. Self-employment is lucrative; for about 20 years in their prime age years self-employed businesswomen enjoy high wages. However, their trajectory indicates a comparatively short-lived success.

Human capital is irrelevant for the wages of businesswomen in self- or paid-employment, controlling for a variety of individual and labor market characteristics. While married self-employed businesswomen suffer a loss in wages, salaried businesswomen do not. Interestingly, the latter enjoy an increase in their wages if they have small children. It is also noteworthy that job prestige is not only an important determinant of wages, but counts much more and is much more rewarding for self-employed women. Dire regional macroeconomic conditions affect all women equally negatively. Surprisingly, results on ethnicity are not strong. Compared to West Germans, neither EU or non-EU immigrants nor East Germans are discernibly different. In entrepreneurial jobs in self- or paid employment ethnicity evidently does not provide an advantage or disadvantage. Years-since-migration is not a significant determinant either. While the self-employed are a random sample, the other salaried women are negatively self-selected in the labor market.

A counterfactual analysis shows that if self-employed businesswomen had the characteristics of their salaried counterparts they would thrive in self-employment. Put differently, if salaried businesswomen were to move to self-employment they would flourish, earning more as self-employed and for a longer period. This exercise shows that it is the self-employment sector that makes a difference in performance, not the characteristics of the salaried businesswomen.

Another simulation that places the self-employed businesswomen in the salaried sector 
demonstrates that the salaried sector is not a good alternative for the self-employed. In fact, self-employed women are worse off if they switch to the salaried sector. Therefore, the self-employment sector does offer opportunities and high rewards to businesswomen. Perhaps the "free" structure of the self-employment sector induces and creates a better fit between characteristics and the job. Still, highly qualified businesswomen value the security of paid-employment and go into it.

The paper shows that self-employment is not just another viable option but a successful one. Especially now, Germany needs new businesses and higher labor force participation, and women who have the skills in ingenuity should delve into this untapped market. While the labor force participation of skilled and talented women in Germany remains low, realizing that ethnicity is not important for entrepreneurship is encouraging and liberating for minority women.

\section{Notes}

1. For a detailed description of this multinomial logit estimation and results see Constant (2006).

2. The handful of ethnic Germans in the dataset is grouped together with the East Europeans.

3. The standard OLS unadjusted wage results are available upon request. They pertain to all women in the three employment types pooled together. Controlling for self-employment and business career, in reference to another job in the wage sector, self-employed earn more.

4. The odd hours of the schools make it difficult for women with children to work full-time, and the tax structure makes the additional labor income unappealing.

\section{References}

Audretsch, D.B., Thurik, R., Verheul, I. and Wennekers, S. (2002), Entrepreneurship: Determinants and Policy in a European-U.S. Comparison, Boston: Kluwer Academic Publishers.

Blanchflower, D.G., Oswald, A. and Stutzer, A. (2001), "Latent Entrepreneurship Across Nations,” European Economic Review, Vol. 45 Nos 4-6, pp. 680-691.

Borjas, G.J. (1986), “The Self-Employment Experience of Immigrants,” Journal of Human Resources, Vol. 21 No. 4, pp. 485-506.

Chiswick, B.R. (1978), “The Effect of Americanization on the Earnings of Foreign-Born Men,” Journal of Political Economy, Vol. 86 No. 5, pp. 897-922.

Clark, K. and Drinkwater, S. (1998), “Ethnicity and Self-employment in Britain,” Oxford Bulletin of Economics and Statistics, Vol. 60 No. 3, pp. 383-407. 
Constant, A. (2006), “Female Proclivity to the World of Business,” Kyklos, Vol. 59 No. 4, pp. 465-480.

Constant, A. and Schultz-Nielsen, M.L. (2004), “Immigrant Self-employment and Economic Performance,” in Migrants, Work, and the Welfare State, Tranæs, T. and Zimmermann, K.F., editors. University Press of Southern Denmark: Odense.

Constant, A. and Shachmurove, Y. (2006), "Entrepreneurial Ventures and Wage Differentials between Germans and Immigrants,” International Journal of Manpower, Vol. 27 No. 3, pp. 208-229.

Constant, A. and Zimmermann, K.F. (2006), “The Making of Entrepreneurs in Germany: Are Native Men and Immigrants Alike?,” Small Business Economics, Vol. 26 No. 3, pp. 279-300.

Constant, A. and Zimmermann, K.F. (2004), "Self-employment Dynamics Across the Business Cycle; Migrants versus Natives,” IZA Discussion Paper No. 1386, Bonn.

Fairlie, R.W. and Meyer, B.D. (1996), “Ethnic and Racial Self-employment Differences and Possible Explanations,” Journal of Human Resources, Vol. 31 No. 4, pp. 757-793.

Forbes.com. (2001), “America’s Top Businesswomen,” http://www.forbes.com/2001/03/28/0327women.html

Georgellis, Y. and Wall, H.J. (2000), “Gender Differences in Self-Employment: Panel Evidence from the Former West Germany,” FED of St. Louis WP No. 1999-008B, St. Louis.

Lee, L-F. (1983), “Generalized Econometric Models with Selectivity,” Econometrica, Vol. 51 No.2, pp. 507-512.

Lofstrom, M. (2002), “Labor Market Assimilation and the Self-employment Decision of Immigrant Entrepreneurs,” Journal of Population Economics, Vol. 15 No. 1, pp. 83-114.

Lohmann, H. (2001), “Self-employed or Employee, Full-time or Part-time? Gender Differences in the determinants and Conditions for Self-employment in Europe and the US,” MZES DP No. 38, Mannheim.

McManus, P.A. (2001), “Occupational Choice and Career Experiences,” Vierteljahrshefte zuer Wirtschaftsforschung, Vol. 70, pp. 24-30.

OECD. (2000), Small and Medium Enterprise Outlook.

Taylor, M.P. (2001), "Self-Employment and Windfall Gains in Britain: Evidence from Panel Data,” Economica, Vol. 68 No. 272, pp. 539-565.

US Bureau Economic Censuses. (2002), “Survey of Business Owners,” http://www.census.gov/csd/sbo/ Wagner, J. (2004), “What a Difference a Y Makes: Female and Male Nascent Entrepreneurs in Germany,” IZA Discussion Paper No. 1134, Bonn. 
Table I. Selected characteristics by ethnicity and occupation

\begin{tabular}{|c|c|c|c|c|c|c|}
\hline & & $\begin{array}{c}\text { Native West } \\
\text { Germans }\end{array}$ & $\begin{array}{l}\text { Native East } \\
\text { Germans }\end{array}$ & $\begin{array}{l}\text { European } \\
\text { Immigrants }\end{array}$ & $\begin{array}{l}\text { Non-EU } \\
\text { Immigrants }\end{array}$ & $\begin{array}{l}\text { Obser } \\
\text { vation }\end{array}$ \\
\hline \multirow{11}{*}{$\begin{array}{l}\text { Self-Employed } \\
\text { Businesswomen }\end{array}$} & Hourly Wages in $€$ uros & 19.12 & 12.23 & 27.66 & 13.78 & \multirow{11}{*}{320} \\
\hline & Gross Monthly Earnings (€) & 2,987 & 2,405 & 3,606 & 1,500 & \\
\hline & Hours Work per Week & 35.41 & 44.95 & 33.82 & 27.00 & \\
\hline & Length of Time in Business & 8.78 & 6.61 & 12.06 & 4.73 & \\
\hline & Treiman Prestige Scores & 51.70 & 48.75 & 49.43 & 49.75 & \\
\hline & Work in Small Company & 0.80 & 0.86 & 0.79 & 0.60 & \\
\hline & Age & 45.14 & 47.47 & 44.86 & 46.10 & \\
\hline & Married & 0.77 & 0.72 & 0.93 & 0.78 & \\
\hline & Years of Education in Germany & 13.97 & 15.56 & 6.18 & 8.00 & \\
\hline & $\begin{array}{l}\text { Years of Education in the } \\
\text { Home } \\
\text { Country }\end{array}$ & 0.11 & & 6.04 & 8.30 & \\
\hline & Years-Since-Migration & & & 20.57 & 16.50 & \\
\hline \multirow{11}{*}{$\begin{array}{l}\text { Salaried } \\
\text { Businesswomen }\end{array}$} & Hourly Wages in $€$ uros & 18.80 & 15.40 & 20.57 & 18.83 & \multirow{11}{*}{706} \\
\hline & Gross Monthly Earnings (€) & 3,012 & 2,735 & 4,078 & 3,077 & \\
\hline & Hours Work per Week & 38.68 & 42.53 & 45.79 & 33.72 & \\
\hline & Length of Time with the Firm & 10.93 & 10.84 & 9.08 & 6.40 & \\
\hline & Treiman Prestige Scores & 56.83 & 56.11 & 56.71 & 56.67 & \\
\hline & Work in Small Company & 0.04 & 0.04 & 0.00 & 0.11 & \\
\hline & Age & 42.75 & 42.72 & 38.12 & 43.44 & \\
\hline & Married & 0.66 & 0.66 & 0.59 & 0.77 & \\
\hline & Years of Education in Germany & 16.08 & 17.75 & 12.62 & 11.67 & \\
\hline & $\begin{array}{l}\text { Years of Education in the } \\
\text { Home Country }\end{array}$ & 0.10 & & 3.82 & 6.33 & \\
\hline & Years-Since-Migration & & & 10.76 & 12.33 & \\
\hline \multirow{11}{*}{$\begin{array}{l}\text { Employees in } \\
\text { Other Wage Work }\end{array}$} & Hourly Wages in €uros & 12.17 & 9.80 & 11.81 & 10.06 & \multirow{11}{*}{4,141} \\
\hline & Gross Monthly Earnings (€) & 1,563 & 1,519 & 1,521 & 1,329 & \\
\hline & Hours Work per Week & 29.85 & 36.43 & 30.29 & 29.90 & \\
\hline & Length of Time with the Firm & 9.91 & 7.87 & 8.37 & 7.02 & \\
\hline & Treiman Prestige Scores & 42.12 & 42.50 & 38.34 & 34.95 & \\
\hline & Work in Small Company & 0.12 & 0.11 & 0.07 & 0.12 & \\
\hline & Age & 42.13 & 39.64 & 40.04 & 38.78 & \\
\hline & Married & 0.68 & 0.64 & 0.72 & 0.72 & \\
\hline & Years of Education in Germany & 12.16 & 14.08 & 7.82 & 5.99 & \\
\hline & $\begin{array}{l}\text { Years of Education in the } \\
\text { Home Country }\end{array}$ & 0.23 & 0.04 & 2.66 & 4.29 & \\
\hline & Years-Since-Migration & & & 16.78 & 13.50 & \\
\hline \multicolumn{2}{|c|}{ Number of Observations } & 3,715 & 792 & 230 & 430 & 5,167 \\
\hline
\end{tabular}


Table II. Wage results adjusted for selection by occupation

\begin{tabular}{|c|c|c|c|}
\hline Independent Variables & $\begin{array}{c}\text { Self-Employed } \\
\text { Businesswomen } \\
\text { (1) }\end{array}$ & $\begin{array}{c}\text { Salaried } \\
\text { Businesswomen } \\
(2)\end{array}$ & $\begin{array}{c}\text { Women in Other } \\
\text { Wage Work } \\
\text { (3) }\end{array}$ \\
\hline Constant & $\begin{array}{c}-0.543 \\
(1.577)\end{array}$ & $\begin{array}{c}1.853^{* * *} \\
(0.669)\end{array}$ & $\begin{array}{c}1.251^{* * *} \\
(0.117)\end{array}$ \\
\hline Age & $\begin{array}{c}0.136 * * * \\
(0.045)\end{array}$ & $\begin{array}{c}0.043 * * \\
(0.020)\end{array}$ & $\begin{array}{c}0.015^{* *} \\
(0.006)\end{array}$ \\
\hline Age $^{2}$ & $\begin{array}{c}-0.002^{* * *} \\
(0.0005)\end{array}$ & $\begin{array}{c}-0.0004^{*} \\
(0.0004)\end{array}$ & $\begin{array}{l}-0.0001 * \\
(0.0001)\end{array}$ \\
\hline Years-Since-Migration & $\begin{array}{c}0.059 \\
(0.043)\end{array}$ & $\begin{array}{l}-0.013 \\
(0.014)\end{array}$ & $\begin{array}{c}0.002 \\
(0.004)\end{array}$ \\
\hline Years-Since-Migration² & $\begin{array}{c}-0.001 \\
(0.001)\end{array}$ & $\begin{array}{c}0.0004 \\
(0.0004)\end{array}$ & $\begin{array}{c}-0.00001 \\
(0.0001)\end{array}$ \\
\hline Years of Education in the Home Country & $\begin{array}{c}-0.044 \\
(0.040)\end{array}$ & $\begin{array}{l}-0.008 \\
(0.017)\end{array}$ & $\begin{array}{c}0.023 * * * \\
(0.004)\end{array}$ \\
\hline Years of Education in Germany & $\begin{array}{l}-0.026 \\
(0.021)\end{array}$ & $\begin{array}{l}-0.012 \\
(0.014)\end{array}$ & $\begin{array}{c}0.026 * * * \\
(0.003)\end{array}$ \\
\hline Poor Health & $\begin{array}{l}-0.165 \\
(0.155)\end{array}$ & $\begin{array}{l}-0.092 * \\
(0.052)\end{array}$ & $\begin{array}{c}-0.047 * * \\
(0.021)\end{array}$ \\
\hline Married & $\begin{array}{c}-0.230 * * \\
(0.109)\end{array}$ & $\begin{array}{l}-0.009 \\
(0.034)\end{array}$ & $\begin{array}{l}-0.025 \\
(0.016)\end{array}$ \\
\hline Have Children under 16 in the Household & $\begin{array}{l}-0.076 \\
(0.102)\end{array}$ & $\begin{array}{c}0.090 * * \\
(0.038)\end{array}$ & $\begin{array}{c}0.034^{* *} \\
(0.017)\end{array}$ \\
\hline Work in a Small Company & $\begin{array}{c}0.088 \\
(0.215)\end{array}$ & $\begin{array}{c}-0.305^{* * *} \\
(0.070)\end{array}$ & $\begin{array}{c}-0.352 * * * \\
(0.021)\end{array}$ \\
\hline Work in an Average Company & $\begin{array}{c}0.201 \\
(0.235)\end{array}$ & $\begin{array}{l}-0.037 \\
(0.030)\end{array}$ & $\begin{array}{c}-0.146^{* * *} \\
(0.013)\end{array}$ \\
\hline Length of Time in Business or Firm & $\begin{array}{c}0.009 \\
(0.006)\end{array}$ & $\begin{array}{c}0.007 * * * \\
(0.002)\end{array}$ & $\begin{array}{c}0.010^{* * * *} \\
(0.001)\end{array}$ \\
\hline Treiman Prestige Score & $\begin{array}{c}0.031 * * * \\
(0.004)\end{array}$ & $\begin{array}{c}0.006 * * * \\
(0.001)\end{array}$ & $\begin{array}{c}0.011 * * * \\
(0.001)\end{array}$ \\
\hline Unemployment over Vacancies Ratio & $\begin{array}{l}-0.021^{*} \\
(0.011)\end{array}$ & $\begin{array}{c}-0.016^{* * *} \\
(0.004)\end{array}$ & $\begin{array}{c}-0.019 * * * \\
(0.002)\end{array}$ \\
\hline Service Industry & $\begin{array}{l}-0.280 \\
(0.234)\end{array}$ & $\begin{array}{c}0.003 \\
(0.125)\end{array}$ & $\begin{array}{c}0.034 \\
(0.038)\end{array}$ \\
\hline Retail/Wholesale Industry & $\begin{array}{l}-0.404 \\
(0.249)\end{array}$ & $\begin{array}{c}-0.233^{*} \\
(0.129)\end{array}$ & $\begin{array}{c}0.053 \\
(0.037)\end{array}$ \\
\hline Government & $\begin{array}{c}0.176 \\
(0.226)\end{array}$ & $\begin{array}{l}-0.105 \\
(0.119)\end{array}$ & $\begin{array}{c}0.103 * * * \\
(0.036)\end{array}$ \\
\hline Manufacturing & $\begin{array}{c}-0.502 * \\
(0.265)\end{array}$ & $\begin{array}{c}0.012 \\
(0.123)\end{array}$ & $\begin{array}{c}0.078 * * \\
(0.037)\end{array}$ \\
\hline Construction & $\begin{array}{l}-0.129 \\
(0.333)\end{array}$ & $\begin{array}{l}-0.187 \\
(0.152)\end{array}$ & $\begin{array}{c}0.079 \\
(0.058)\end{array}$ \\
\hline Financial/Banking Industry & $\begin{array}{l}-0.268 \\
(0.229)\end{array}$ & $\begin{array}{c}0.096 \\
(0.123)\end{array}$ & $\begin{array}{c}0.178 * * * \\
(0.038)\end{array}$ \\
\hline Naturalized Citizen & $\begin{array}{c}0.328 \\
(0.423)\end{array}$ & $\begin{array}{c}-0.042 \\
(0.147)\end{array}$ & $\begin{array}{c}0.018 \\
(0.034)\end{array}$ \\
\hline European Immigrant & $\begin{array}{c}0.292 \\
(0.319)\end{array}$ & $\begin{array}{c}0.105 \\
(0.105)\end{array}$ & $\begin{array}{c}0.043 \\
(0.034)\end{array}$ \\
\hline Non-EU Immigrant & $\begin{array}{l}-0.237 \\
(0.487)\end{array}$ & $\begin{array}{c}0.018 \\
(0.150)\end{array}$ & $\begin{array}{c}0.030 \\
(0.031)\end{array}$ \\
\hline Native East German & $\begin{array}{c}0.028 \\
(0.157)\end{array}$ & $\begin{array}{l}-0.070 \\
(0.045)\end{array}$ & $\begin{array}{c}-0.109 * * * \\
(0.021)\end{array}$ \\
\hline
\end{tabular}


Table II. Wage results adjusted for selection by occupation

\begin{tabular}{lccc}
\hline Independent Variables & $\begin{array}{c}\text { Self-Employed } \\
\text { Businesswomen } \\
(1)\end{array}$ & $\begin{array}{c}\text { Salaried } \\
\text { Businesswomen } \\
(2)\end{array}$ & $\begin{array}{c}\text { Women in Other } \\
\text { Wage Work } \\
(3)\end{array}$ \\
\hline Selection Term $\lambda$ & -0.251 & $-0.161^{*}$ & $-0.099^{* * *}$ \\
& $(0.262)$ & $(0.087)$ & $(0.031)$ \\
Mean log-hourly-wage & 2.559 & 2.818 & 2.330 \\
(standard deviation) & $(0.902)$ & $(0.426)$ & $(0.488)$ \\
Log-Likelihood & -333.287 & -275.541 & $-1,995.849$ \\
$\mathrm{R}^{2}$ & 0.369 & 0.270 & 0.350 \\
$\mathrm{~F}[25, \quad(294)(680)(4115)]$ & 6.87 & 10.04 & 88.75 \\
Number of Observations & 320 & 706 & 4,141 \\
Notes: $* * *$ significance at the 1 percent level in a two-tail test; $* *$ significance at the 5 percent level in a two-tail \\
test; * significance at the 10 percent level in a two-tail test. Robust standard errors in parentheses
\end{tabular}




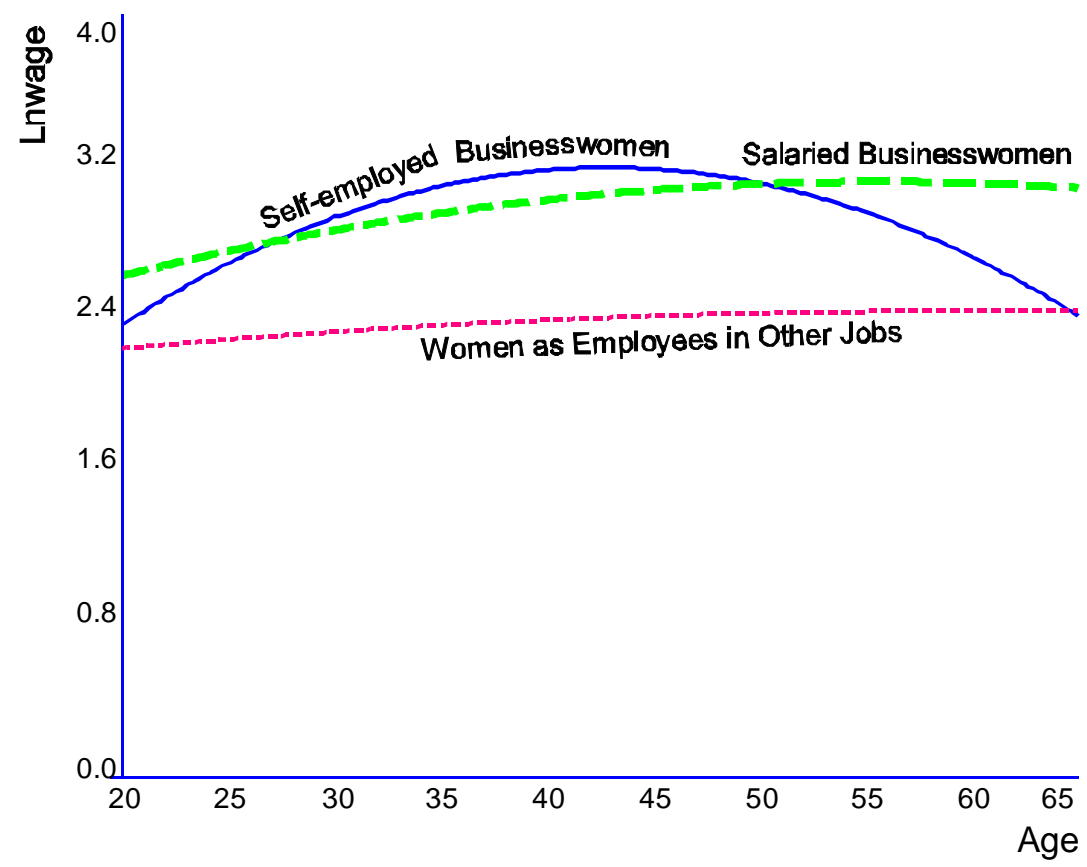

Figure 1. Log-wage-age profiles by occupation

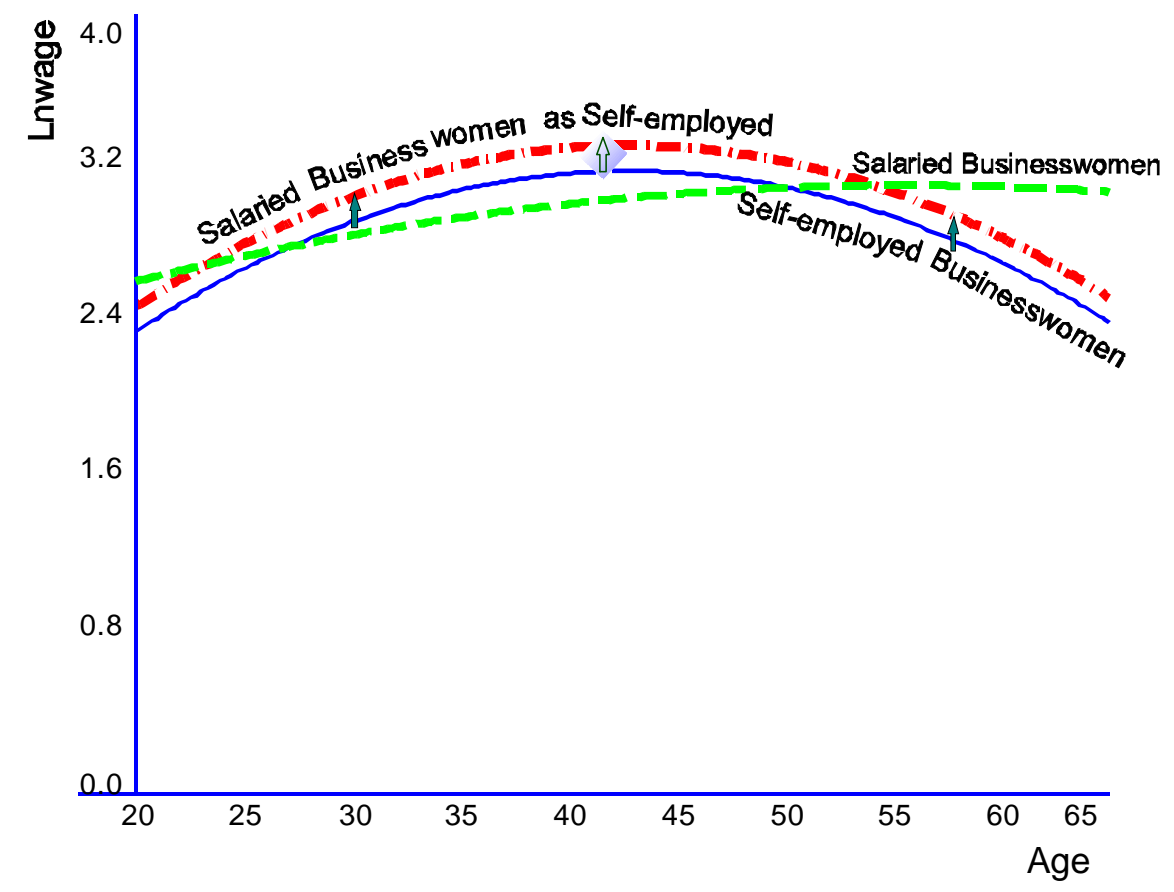

Figure 2. Counterfactual: Salaried businesswomen as self-employed 


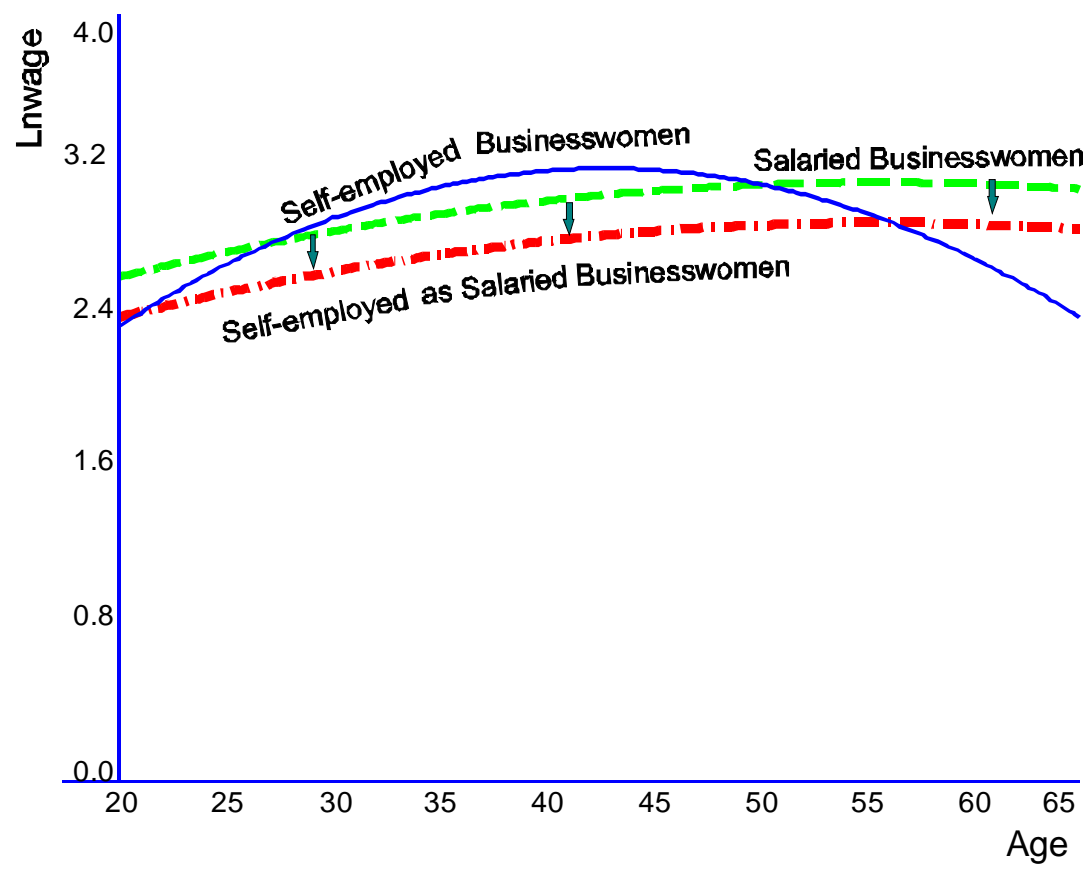

Figure 3. Counterfactual: Self-employed as salaried businesswomen

\section{Appendix}

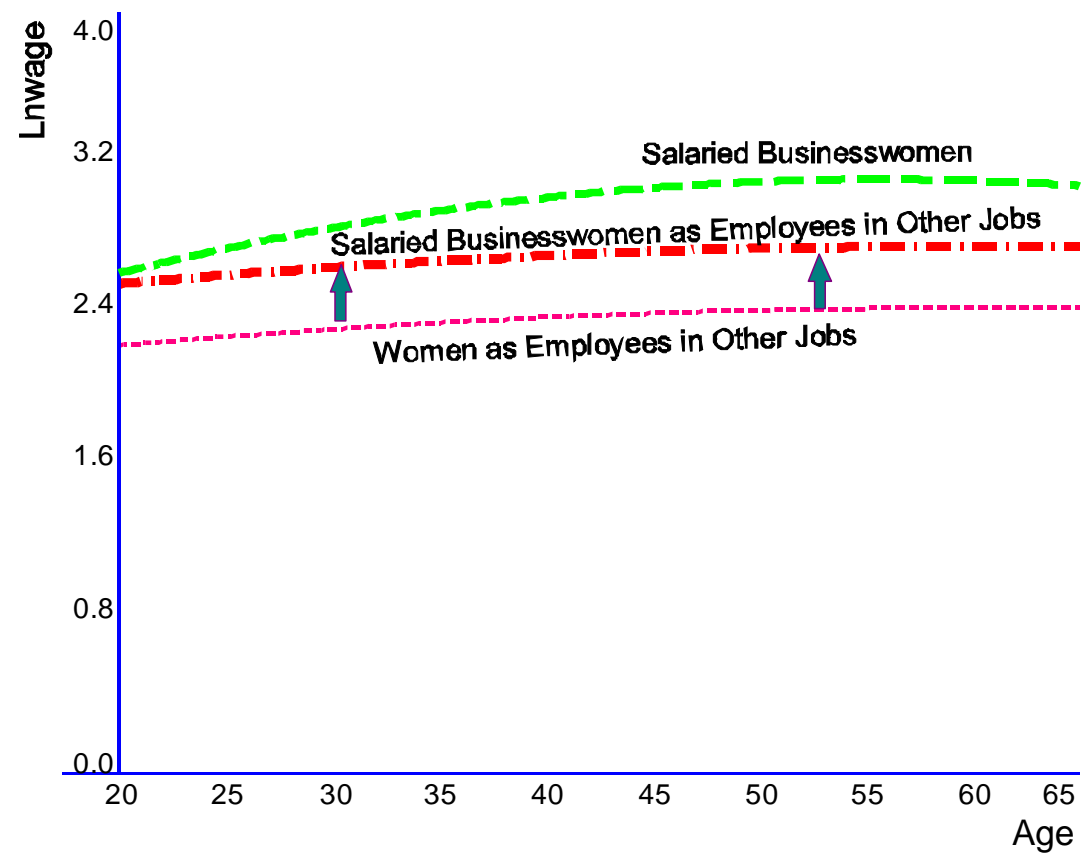

Figure A1. Counterfactual: Salaried businesswomen as employees in other jobs 